\title{
PROGRAM OF THE FIFTY-FIFTH ANNUAL MEETING OF THE AMERICAN SOCIETY FOR CLINICAL INVESTIGATION, INC., TO BE HELD IN ATLANTIC CITY, NEW JERSEY, APRIL 29, 1963
}

1. Chronology and Pattern of Human Chromosome Replication. Y. Kikuchi and Avery A. Sandberg,* Buffalo, N. Y.

2. Enhanced Mutagenicity of Virus-bound Carcinogens. Christopher M. Martin and Dean F. Gray, Jersey City, N. J. (introduced by Harry J. Robinson).

3. Neonatal Unconjugated Hyperbilirubinemia Associated with Breast-Feeding and a Factor in Milk That Inhibits Glucuronide Formation In Vitro. IRwiN M. Arias, Lawrence M. Gartner, Sam Seifter, and Mathilda Furman, New York, N. Y. (introduced by M. Henry Williams, Jr.).

4. The Distinctive Detergent Properties of Conjugated Bile Salts and Their Relation to the Role of Bile Salts in Fat Digestion. Alan F. Hofmann and Bengt Borgström, New York, N. Y., and Lund, Sweden (introduced by Jules Hirsch).

5. Important Determinants in Resistance to Pulmonary Infection. Gustale A. Laurenzi, Raul B. Endriga, Joseph J. Guarneri, and John P. Carey, Jersey City, N. J. (introduced by Timothy J. Regan).

6. Infection of Volunteers with Artificially Propagated Eaton Agent (Mycoplasma pneumoniae): Implications for Development of Attenuated Vaccine for Cold Agglutinin Positive Pneumonia. R. B. Couch, T. R. Cate, and R. M. Chanock,* Bethesda, Md.

7. The Ability of Different Donor Cell Constituents to Shorten or Prolong Homograft Survival. Halsted Holman,* Alexander Fefer, and William C. Davis, Palo Alto, Calif.

8. Evolution of Delayed Hypersensitivity Observed in the Electron Microscope with Ferritin, conjugated Tuberculin Antigen. Walter L. Norton and MorRIS ZiFF,* Dallas, Tex.

9. Identification of Complement Antigens Coating Red Cells in Acquired Hemolytic Anemia. H. J. MüllerEberhard,* H. Fudenberg, M. Harboe, and P. L. Mollison, New York, N. Y.

10. A Mechanism of Viruria. C. Larkin Flanagan and Irwin Schlltz, Chicago, Ill. (introduced by David P. Earle).

11. Hypoglycemia : Potent Stimulus to Growth Hormone Secretions. Seymour M. Glick, Jesse Roth, Rosalyn S. Yalow, and Solomon A. Berson,* Bronx, N. Y.

* Member of ASCI.
12. Evidence for a Stimulatory Feedback of Ketone Acids on Pancreatic Beta Cells. Leonard L. Madison,* David Mebane, and Amanda Lochner, Dallas, Tex.

13. The Relationship between Vitamin D and Parathyroid Hormone. Howard Rasmussen,* Hector F. Deluca, John D. Sallis, and George W. ExgStrom, Madison, Wis.

14. Steroid-dependent Increase of Nerve Conduction Velocity in Adrenal Insufficiency. R. I. HenkIN, J. R. Gill, JR., J. R. Warmolts, A. A. Carr, and F. C. Bartter,* Bethesda, Md.

15. A Role of Mitochrondria in Iron Metabolism of Developing Erythroyctes. Richard G. CoOper, Leslie T. Webster, Jr., and John W. Harris,* Cleveland, Ohio.

16. Intestinal Mucosal Mechanisms Controlling Iron Absorption. Marcel E. Conrad and William $\mathrm{H}$. Crosby,* Washington, D. C.

17. Endogenous Carbon Monoxide Production in Patients with Hemolytic Anemia. R. F. Coburn, W. J. WiLliams, S. B. Kahn, and R. E. Forster,* Philadelphia, Pa.

18. Sonic Measurement of Bone Mass. Clayton Rich, Eli J. Klink, Gay L. Mullins, and C. Benjamin Graham, Seattle, Wash. (introduced by Belding $\mathrm{H}$. Scribner).

19. Physiologic Studies of Antidiuretic Hormone (ADH) by its Direct Measurement in Human Plasma. WALter J. Czaczkes and Charles R. Kleeman,* Los Angeles, Calif.

20. Augmented Natriuretic Response to Acute Sodium Infusion Following Blood Pressure Elevation with Metaraminol in Normotensive Subjects. Carlos A. VaAmonde, I. Norman Sporn, Ruben G. Lancestremere, Joseph L. Belsky, and Solomon Papper,* Boston, Mass., Richmond, Va., and Albuquerque, N. Mex.

21. The Mechanism of Sodium Diuresis after Saline Loading: Evidence for a Factor Other than Increased Filtered Sodium and Decreased Aldosterone. Norman G. Levinsky and Richard C. Lalone, Boston, Mass. (introduced by Chester S. Keefer).

22. Circulatory Consequence of Changes in Cardiac Rhythm Produced in Patients by Transthoracic Direct Current Shock. John S. Graettinger, Richard A. Carleton, and Joseph J. Muenster, Chicago, Ill. (introduced by Theodore B. Schwartz). 
23. Fine Structural Basis of Starling's Law of the Heart. Edmund H. Sonnenblink, Thomas S. Cottrell, and David Spiro, New York, N. Y. (introduced by John V. Taggart).

24. The Diagnosis of Myocardial Infarcts by Photoscanning after Administration of Cesium ${ }^{132}$. EDWARD A. Carr, Jr., Barbara J. Walker, and John Bartlett, JR., Ann Arbor, Mich. (introduced by Fred M. Davenport).
25. Potassium Depletion-A Disorder of the Pasteur Effect. Robert P. Davis and Gladys F. Rand, New York, N. Y. (introduced by Quentin B. Deming).

26. Evidence for Active Transport Regulation of Cerebral Spinal Fluid $\mathrm{pH}$ and Its Effect on the Regulation of Respiration. J. W. Severinghaus * and R. A. Mrtchell, San Francisco, Calif.

\title{
LISTING OF EXHIBITS AT THE FIFTY-FIFTH ANNUAL MEETING OF THE AMERICAN SOCIETY FOR CLINICAL INVESTIGATION, INC., 1963 SCIENTIFIC EXHIBIT
}

\author{
DEVELOPMENT OF VITAMIN DEFICIENCY : THIAMINE
}

BY

MYRON BRIN

Upstate Medical Center, State University of New York, Syracuse, N. Y.

\section{TECHNICAL EXHIBITS}

\begin{tabular}{|c|c|}
\hline AввOTT LABORATORIES & \#38 \\
\hline AdVANCED InStruments, InC. & \#9 \\
\hline American Optical Co., Instrument Div. & \#46 \& 47 \\
\hline Avionics Research Products Corp. & \#16 \\
\hline Becton, Dickinson and Co.* & \#39 \\
\hline Blakiston Div., McGraw-Hill Book Co., Inc.* & \#10 \\
\hline BUCHLER INSTRUMENTS, INC.* & \#48 \\
\hline Calbiochem & \#14 \\
\hline Coulter Electronics Sales Co. & \#25 \\
\hline F. A. Davis Co. & \#5 \\
\hline Electronics for Medicine, Inc. & \#35 \& 36 \\
\hline F \& M Scientific Corp.* & \#43 \\
\hline General Diagnostics Div., Warner-Chilcott Labs. & $\# 30$ \\
\hline GILFORD INSTRUMENT LABORATORIES, INC.* & \#37 \\
\hline Grune \& Stratton, Inc.* & \#22 \\
\hline Harvard Apparatus Co., Inc. & \#40 \\
\hline Hoeber Medical Div., Harper \& Row & \#33 \\
\hline INSTITUTE FOR SCIENTIFIC INFORMATION & \#55 \\
\hline INSTRUMENTATION AsSOCIATES, INC.* & \#3 \& 4 \\
\hline INSTRUMENTATION LABORATORY, INC.* & $\# 49$ \\
\hline Jonker Business Machines, Inc. & \#53 \\
\hline LEA \& FEBIGER & \#21 \\
\hline E. LEITz, Inc.* & \#28 \\
\hline J. B. Lippincott Co. & \#24 \\
\hline
\end{tabular}

Little, Brown and Co.* \#29 The Macmillan Co. \#26. Millipore Filter Corp. \#13 MNEMOTRON * \#15

* See advertisement in this issue. 